\title{
PENDIDIKAN AGAMA KRISTEN DALAM MEMBANGUN WAWASAN KEBANGSAAN MENGHADAPI ISU INTOLERANSI DAN RADIKALISME
}

\author{
Ramot Peter \\ Character Building Development Center, Information Systems Department, School of \\ Information Systems, Bina Nusantara University, Jakarta, Indonesia 11480 \\ ramot.peter@binus.ac.id
}

Diterima tanggal: 16 Juni 2020

Dipublikasikan tanggal: 27 Desember 2020

\begin{abstract}
ABSTRAK
Isu-isu intoleransi dan radikalisme sudah merasuki dimensi pendidikan di Indonesia. Perilaku buruk peserta didik yang mengarah pada intoleransi dan radikalisme sudah meresahkan kehidupan berbangsa. Pemerintah menyikapi permasalahan tersebut dengan mencanangkan program pendidikan karakter dan gerakan revolusi mental. Program dan gerakan tersebut masih belum maksimal berdampak sehingga perlu melibatkan dunia pendidikan. Penelitian ini perlu dilakukan untuk mengidentifikasi pemahaman peserta didik tentang pentingnya pembelajaran PAK dalam rangka pembentukan karakter berwawasan kebangsaan; menemukan pemahaman peserta didik dalam menyikapi bahaya radikalisme dan intoleransi; dan, memberikan alternatif solusi untuk membentuk karakter berwawasan kebangsaan dalam mencegah intoleransi dan radikalisme. Metode yang digunakan dalam penelitian ini adalah metode kualitatif dengan pendekatan deskriptif-analitis dengan menggunakan berbagai data yang diperoleh melalui wawancara dan kuesioner sebagai data primer dan sekunder melalui buku-buku, jurnal, majalah, surat kabar dan sumber-sumber relevan lainnya. Setelah wawancara secara tidak terstruktur, penyuluhan dilakukan untuk pengayaan dan selanjutnya penyebaran kuesioner kepada peserta didik. Penelitian diadakan di Panti Asuhan Asih Lestari Jakarta terhadap penghuni panti yang disebut peserta didik dari berbagai tingkatan dan usia. Hasil pengumpulan data kuesioner menunjukkan bahwa: pertama, peserta didik memahami dengan yakin bahwa pembelajaran PAK sangat mendukung untuk membangun karakter berwawasan kebangsaan; kedua, peserta didik mampu untuk menyatakan sikap terhadap bahaya intoleransi dan radikalisme; ketiga, pembentukan karakter berwawasan kebangsaan sebagai upaya untuk mendukung gerakan revolusi mental dan alternatif solusi untuk mencegah intoleransi dan radikalisme. Dengan demikian maka semua Pendidikan Kristen diharapkan mampu mengembangkan pembelajaran PAK sebagai sarana pembentukan karakter berwawasan kebangsaan sehingga peserta didik memiliki sikap nasionalisme untuk pencegahan bahaya tindakan intoleransi dan radikalisme.
\end{abstract}

Kata kunci: Revolusi mental, pendidikan karakter, wawasan kebangsaan

\section{ABSTRACT}

The issues of intolerance and radicalism have penetrated the dimensions of education in Indonesia. The bad behavior of students that leads to intolerance and radicalism has disturbed the life of the nation. The government is addressing these problems by launching a character education program and a mental revolution movement. These programs and movements have not had a maximum impact so they need to involve the world of education. This research needs to be done to identify students' understanding of the importance of PAK learning in the context of building a national character; find students' understanding in addressing the dangers of radicalism and intolerance; and, providing alternative solutions to form a nationalistic character in preventing intolerance and radicalism. The method used in this research is a qualitative method with a descriptive-analytical approach using various data obtained through interviews and questionnaires as primary and secondary data through books, 
journals, magazines, newspapers and other relevant sources. After an unstructured interview, counseling was carried out for enrichment and further distribution of questionnaires to students. The research was conducted at the Asih Lestari Jakarta Orphanage on the residents of the orphanage called students of various levels and ages. The results of the questionnaire data collection show that: first, students understand with confidence that PAK learning is very supportive of building national-minded character; second, students are able to express attitudes towards the dangers of intolerance and radicalism; third, the formation of a national-minded character as an effort to support the mental revolution movement and alternative solutions to prevent intolerance and radicalism. Thus, all Christian Education is expected to be able to develop PAK learning as a means of building nationalistic character so that students have a nationalistic attitude to prevent the dangers of intolerance and radicalism.

Keywords: Mental revolution, character education, nationalism values.

\section{PENDAHULUAN}

Penulis mengamati ada banyak permasalahan yang dihadapi oleh bangsa Indonesia saat ini seperti adanya tindakan-tindakan radikalisme dan intoleransi yang ingin memecahbelah kehidupan umat beragama. Hal ini didukung data yang dikutip oleh Martina Novalina dari sebuah hasil survei yang dilakukan oleh The Pew Research Center yang menyatakan bahwa Indonesia menganggap isu radikalisme adalah ancaman terbesar bagi bangsa ini dengan persentase sebesar 74\% dibandingkan masalah lainnya. (Novalina, 2020) Pelaku sangat bervariasi, bahkan merasuki dunia pendidikan mulai dari tingkat dasar hingga perguruan tinggi. Ada banyak pemberitaan tentang hal tersebut, di antaranya: 1) Pelajar SMA di Padang, Sukabumi, dan Solo dianggap paling rentan terpapar radikalisme (BBC News, 2018); 2) Ketika paham radikal masuk ke ruang kelas sekolah (BBC News, 2016); 3) Radikalisme yang menyebar secara senyap pada remaja dan pemuda (NU Online, 2018). Kasus-kasus tersebut sudah menyejarah sejak masa Orde Baru (Orba) hingga sekarang. Sasarannya, pendidikan sering dijadikan alat penyeragaman (uniformity) dan indoktrinasi politik sebagai usaha untuk menanamkan pemahaman, ideologi, doktrin, dan lain sebagainya kepada seseorang atau sekelompok orang yang dituju.(Nego, 2020; Novalina, 2018; Zhafira, 2017)

Meningkatnya isu-isu radikalisme dan intoleransi akhir-akhir ini cenderung dipicu oleh perkembangan Ilmu Pengetahuan dan Teknologi (IPTEK) yang begitu pesat dan mengglobal. Pada dasarnya, manfaat IPTEK banyak memberikan kemudahan dalam segala aspek kehidupan manusia.(Mawikere, 2020) Namun secara paralel telah terjadi ambivalensi di mana penggunaannya sering dijadikan sarana untuk menyebarkan berita palsu (hoax), pornografi dan pornoaksi, penipuan, dan kejahatan lainnya.(Eliasaputra et al., 2020) Perkembangan IPTEK secara digital juga telah menjadikan masyarakat 
Indonesia bersikap individualistik, radikal dan intoleran terhadap keberagaman bahkan semakin provokatif dalam bermedia sosial. Fenomena buruk tersebut merupakan ATHG (ancaman, tantangan, hambatan, gangguan) terhadap berbagai dimensi kehidupan berbangsa bahkan menimbulkan banyak kekacauan dalam negeri. ATHG yang begitu dinamis dan tidak menentu sebagai dampak perkembangan IPTEK paling banyak berpengaruh pada kehidupan politik. Selain itu juga berpengaruh pada aspek sosial di mana ada banyak praktik-praktik pelanggaran etika dan moral. Jika dibiarkan maka akan menimbulkan kemerosotan karakter dan moral anak bangsa.

Dalam kaitan inilah pemerintahan Jokowi menggulirkan Gerakan Revolusi Mental (GRM) yang merupakan sebuah tindakan korektif terhadap karakter manusia Indonesia sebagai bangsa menuju keserasian sosial (Nainggolan, 2015). Pemikiran ini merupakan suatu pemikiran dan kejutan di tengah maraknya ATHG yang timbul dari tindakan radikalisme dan intoleransi sebagai dampak dari kekurangpekaan terhadap pembentukan karakter anak bangsa. Pada Desember 2016, Presiden mengeluarkan Inpres No. 12 Tahun 2016 tentang Gerakan Nasional Revolusi Mental (GNRM). Gerakan ini dimaksudkan untuk memperbaiki dan membangun karakter anak bangsa yang mengacu kepada nilai-nilai integritas, etos kerja, dan gotong royong untuk membangun budaya bangsa yang bermartabat, modern, maju, makmur, dan sejahtera berdasarkan Pancasila. GRM harus dimulai dari pendidikan, mengingat peran pendidikan sangat strategis dalam membentuk mental anak bangsa (Kristiawan, 2016), yaitu kepada peserta didik selanjutnya kepada masyarakat dan aparatur atau penyelenggara negara. Walau pendidikan masih sering tertinggal dibandingkan pengembangan dimensi ekonomi dan pembangunan infrastruktur namun pemerintah terus berupaya menggaungkan GRM untuk dimasukkan dalam kurikulum pendidikan mulai dari pendidikan dasar hingga perguruan tinggi.

Pada kenyataannya, pendidikan masih belum maksimal dalam mengimplementasikan kebijakan pemerintah sehingga menimbulkan ketimpangan. Bahkan yang sangat memprihatinkan, penyelenggaraan pendidikan di Indonesia ternyata tidak masuk kategori yang humanis atau memanusiakan manusia (Jalaluddin, H., \& Idi, 2011) karena ditemukan persoalan dan pelanggaran kemanusiaan yang terjadi. Hal ini telah merusak tatanan hidup berbangsa sehingga kualitas kehidupan beragama menjadi semu, moralitas pemimpin merosot, dan toleransi kehidupan 
beragama luntur (Tilaar, 2000). Pendidikan diharapkan dapat membangun kembali atau merevitalisasi, dan mewujudkan peradaban bangsa yang bermartabat sebagaimana yang ditegaskan dalam UU SISDIKNAS No. 20 tahun 2003 pasal 3 yang mengatakan: "Pendidikan nasional berfungsi mengembangkan kemampuan dan membentuk watak serta peradaban bangsa yang bermartabat dalam rangka mencerdaskan kehidupan bangsa, bertujuan untuk berkembangnya potensi peserta didik agar menjadi manusia yang beriman dan bertakwa kepada Tuhan Yang Maha Esa, berakhlak mulia, sehat, berilmu, cakap, kreatif, mandiri, dan menjadi warga negara yang demokratis serta bertanggungjawab." Dalam hal ini, sarana paling tepat untuk menghasilkan manusia berkualitas tinggi adalah pendidikan, baik melalui jalur formal maupun non-formal.

Wakil Perdana Menteri Cina Li Lanqing (Li, 2004) mengatakan: "The hope of rejuvenating the nation lies in education, which in turn depends upon teachers." Pernyataan ini mengidentifikasi bahwa kebutuhan terhadap pendidikan yang unggul merupakan tuntutan terhadap kemajuan suatu bangsa di tengah pesatnya perkembangan IPTEK dan juga dalam menghadapi persaingan global. Sistem pendidikan harus dibangun secara totalitas dan terpadu sebagai interaksi dari seperangkat unsur-unsur pendidikan yang saling melengkapi satu sama lain menuju tercapainya tujuan pendidikan yang telah menjadi cita-cita bersama para pelakunya (Mastuhu, 1994). Oleh karena itu, pemerintah perlu menyusun Kurikulum Pendidikan mulai dari tingkat dasar hingga perguruan tinggi yang diserap oleh lembaga penyelenggara pendidikan sebagai acuan mendesain program pembelajaran. Salah satu contoh upaya yang telah diprogramkan oleh Menteri Pendidikan Indonesia Muhadjir Effendy sebelumnya yaitu implementasi sistem full day school sebagai bagian dari pembentukan karakter siswa (Benawa, 2018), namun tidak berjalan dengan baik.

Disamping penyusunan program-program, untuk melaksanakan proses pendidikan dan mencapai tujuan pembelajaran harus didukung dengan pendidik yang profesional dan kemampuan daya serap peserta didik. Pendidik dapat membantu peserta didik untuk mengaktualisasikan setiap domain pembelajaran melalui formulasi kompetensi, dan peserta didik secara bersamaan dengan kemampuan daya serapnya dapat melakukan tindakan moral yang relevan. Jika pendidik hanya sekedar mentransfer pengetahuan, maka hal tersebut belumlah pendidikan, tetapi masih sekedar pengajaran.(MA Widiyanto, 2020; Nuhamara, 2018) Hasil dari proses pendidikan tidak 
hanya melahirkan anak bangsa yang berintelektualitas tetapi juga yang tidak cacat moral dan karakternya. Pendidikan harus menjadi sarana tepat untuk menjadikan seseorang berkompeten dalam menghadapi tantangan-tantangan dalam kehidupan. Setiap lembaga pendidikan dari jenjang dasar hingga perguruan tinggi harus berusaha untuk menghasilkan lulusan-lulusan yang berkualitas (Martono, 2017) yang didukung dengan pembangunan karakter berwawasan kebangsaan untuk menjadi warga negara unggul menuju Indonesia maju.

Ketidakberesan dunia pendidikan suatu bangsa akan berdampak pada kebobrokan karakter. Secara nasional dapat ditemukan dari beberapa pemberitaan media massa, di antaranya: 1) paham radikalisme merasuki dunia pendidikan mulai dari PAUD hingga Perguruan Tinggi (Kasuistika, 2018); 2) 10 perguruan tinggi negeri (PTN) di Indonesia terpapar paham Islam radikalisme (Tirto, 2019); 3) Radikalisme berbalut pendidikan sudah menyasar anak usia dini (Anonim, 2019); 4) 23 persen mahasiswa terpapar radikalisme dan setuju pembentukan negara khilafah (Detiknews, 2019). Betapa kisruhnya dunia pendidikan nasional hingga ada kelompok tertentu dalam dunia pendidikan nasional ingin menghancurkan NKRI dan menentang ideologi Pancasila dengan tindakan intoleransi dan radikalisme agama.

Sebagai bagian dari pendidikan nasional, pendidikan Kristen tidak pantas bersikap seolah lepas tangan dan kurang terlibat. Susanti (2017) berpendapat bahwa upaya pendidikan karakter berwawasan kebangsaan perlu dikembangkan berdasarkan beberapa sumber, yakni Pancasila, agama, budaya, dan tujuan pendidikan nasional. Sebagai sumber agama, pembelajaran Pendidikan Agama Kristen (PAK) menjadi bagian penting dalam meningkatkan sikap nasionalisme sebagai upaya mengatasi kemerosotan karakter anak bangsa. Pandangan ini sesuai dengan kebenaran Firman Tuhan dalam 2 Timotius 3:16 mengatakan "Segala tulisan yang diilhamkan Allah memang bermanfaat untuk mengajar, untuk menyatakan kesalahan, untuk memperbaiki kelakuan dan untuk mendidik orang dalam kebenaran". Oleh karena itu, keutuhan bangsa juga merupakan tanggungjawab pendidikan Kristen dengan ikut terlibat dalam membangun karakter berwawasan kebangsaan. (Pike, 2010) berpandangan bahwa pembentukan karakter generasi muda tidak cukup diselenggarakan di lingkungan pendidikan formal saja, tetapi juga non formal yang dilakukan melalui kerjasama dengan masyarakat, keluarga, gereja dan lembaga masyarakat. 
Berdasarkan latar belakang masalah yang sudah dipaparkan, penulis perlu mengkaji dengan cara mengidentifikasi dan menganalisis pemahaman peserta didik tentang radikalisme dan intolerasi dalam kehidupan berbangsa yang marak akhir-akhir ini. Adapun penelitian ini dilakukan dengan tujuan untuk: 1) mengidentifikasi pemahaman peserta didik tentang pembelajaran PAK untuk pembentukan karakter berwawasan kebangsaan, 2) menemukan pemahaman peserta didik dalam menyikapi bahaya tindakan radikalisme dan intoleransi, dan 3) memberikan alternatif solusi untuk membentuk karakter berwawasan kebangsaan untuk mencegah tindakan intoleransi dan radikalisme.

\section{METODE}

Metode yang dipergunakan dalam penelitian ini adalah metode kualitatif. Penelitian kualitatif dilakukan untuk mencari jawaban pada pertanyaan 'apa, bagaimana, atau mengapa' dari suatu fenomena (Green, 2004). Pertanyaan-pertanyaan tersebut diserap dalam pengumpulan data melalui wawancara dan kuesioner. Setelah wawancara tidak terstruktur, penyuluhan dilakukan untuk pengayaan (treatment) dan selanjutnya dilakukan penyebaran kuesioner sebagai sumber data untuk membuat deskripsi (gambaran) secara sistematis, faktual dan akurat mengenai fakta-fakta, sifatsifat serta hubungan antar fenomena yang diselidiki (Nazir, 2005). Adapun prosedur penelitian dilakukan dengan urutan proses sebagai berikut: 1) pengumpulan data, 2) klasifikasi data, 3) analisis data, dan 4) pengambilan kesimpulan.

Data primer diperoleh melalui wawancara dan kuesioner kepada penghuni panti. Jumlah sampel tertentu sangat diperlukan untuk penelitian kuantitatif; sedangkan untuk penelitian kualitatif tidak ada patokan untuk jumlah sampel karena bukan jumlah sampel yang membuat penelitian kualitatif valid, tetapi kecukupan data yang diperlukan (Kumar, 2011). Artinya, jika jumlah sampel cukup untuk mewakili kelompoknya dan sesuai dengan keperluan penelitian dan analisis data (Tracy, 2013), maka jumlah sampel tersebut dapat dipakai. Sedangkan data sekunder diperoleh dari buku-buku, jurnal, majalah, surat kabar dan sumber-sumber relevan lainnya. Analisa data dilakukan dengan metode analisis isi (content analysis), yaitu usaha untuk menggali isi atau makna pesan simbolik dari sebuah buku atau karya tulis lainnya. 
Penelitian ini dilakukan kepada penghuni Panti Asuhan Asih Lestari yang beralamat di Jalan Gardu No. 1, Kosambi Barat Salembaran Jati, Kecamatan Kosambi, Tangerang Banten 15214. Sebagian besar penghuni merupakan peserta didik yang sedang mengikuti pendidikan formal di beberapa sekolah Kristen dekat lokasi panti. Adapun komposisi penghuni panti sangat bervariasi terdiri dari laki-laki dan perempuan berusia 6 hingga 19 tahun dengan latar belakang pendidikan dari PAUD hingga SMA sebanyak 20 orang. Latar belakang para siswa beragam ditinjau dari suku, budaya, gereja dan latar belakang sosial lainnya. Corak keberagaman sangat mewarnai kehidupan di panti dan sering terjadi konflik ataupun kekerasan yang disebabkan karena perbedaan paham ataupun cara penyampaian yang dipengaruhi oleh latar belakang kesukuan.

\section{HASIL DAN PEMBAHASAN}

Setelah dilakukan wawancara tidak terstruktur terhadap penghuni panti yang disebut sebagai peserta didik dalam penelitian ini, sebagian besar dari mereka kurang memahami tentang intoleransi dan radikalisme yang akhir-akhir ini marak terjadi. Untuk memberikan pengayaan (treatment) maka dilakukan penyuluhan tentang “Gerakan Revolusi Mental melalui PAK Sebagai Upaya Menghadapi Radikalisme dan Intoleransi" yang dilakukan dengan menggunakan metode ceramah dan diskusi. Adapun tujuan penyuluhan ini adalah untuk membangun pemahaman peserta didik di Panti Asuhan Asih Lestari tentang bahaya radikalisme dan intoleransi bagi keutuhan bangsa. Kegiatan ini dilakukan sebagai salah satu bagian proses pembelajaran untuk membangun karakter berwawasan kebangsaan di tengah maraknya tindakan intoleransi dan radikalisme. Sebelum melakukan kegiatan penyuluhan, acara dimulai dengan doa, menyanyikan lagu-lagu Rohani Kristen dan dilanjutkan dengan lagu-lagu Kebangsaan. Selama proses penyuluhan, para peserta didik sangat aktif dan antusias berdiskusi tentang upaya-upaya dalam menghadapi ancaman tindakan radikalisme dan intoleransi.

Para peserta didik mengikuti penyuluhan begitu santai namun tetap serius sehingga mereka dapat mengikuti dan memahami materi yang disampaikan dengan baik. Pemaparan yang disertai dengan games, tanya jawab yang sangat interaktif menjadi motivasi mereka dalam menjawab pertanyaan yang diajukan. Sekalipun pembahasan materi sangat berat untuk dibagikan kepada anak usia antara 6 hingga 19 
tahun namun mereka dapat menyerapnya dengan baik. Hal ini terbukti pada sesi tanya jawab, peneliti menjumpai seorang peserta didik berusia 13 tahun mampu menjelaskan setiap pertanyaan seputar intoleransi dan radikalisme. Bahkan, ada satu pernyataan peserta didik mengatakan: "Saya sedih, akibat kerusuhan banyak merugikan masyarakat umum. Tidak bisa sekolah, tidak bisa bekerja, tidak bisa berjualan, tidak bisa beribadah. Saya berdoa agar tercipta kedamaian di bangsa yang kucintai ini." Hal ini menunjukkan betapa peserta didik memahami betul pentingnya menumbuhkan rasa nasionalisme agar tidak terjadi lagi kerusuhan-kerusuhan sebagai dampak tindakan radikalisme dan intoleransi di tengah keberagaman.

Setelah dilakukan penyuluhan sebagai pengayaan, lalu dilakukan penyebaran kuesioner kepada para peserta didik sebagai penghuni panti. Adapun hasil pengumpulan data melalui penyebaran kuesioner kepada peserta didik dapat dilihat pada tabel di bawah ini: 
Ramot Peter:

Pendidikan Agama Kristen Dalam Membangun Wawasan Kebangsaan

Menghadapi Isu Intoleransi Dan Radikalisme

Tabel 1. Hasil Kuesioner

\begin{tabular}{|c|c|c|c|c|c|c|c|c|c|c|c|c|}
\hline No & Pertanyaan & SS & $\%$ & $\mathbf{S}$ & $\%$ & RG & $\%$ & TS & $\%$ & STS & $\%$ & Jml \\
\hline 1 & $\begin{array}{l}\text { Pembelajaran Pendidikan Agama } \\
\text { Kristen dapat membantu peserta didik } \\
\text { memahami bahaya tindakan } \\
\text { intoleransi dan radikalisme. }\end{array}$ & 10 & 50 & 10 & 50 & & & & & & & 20 \\
\hline 2 & $\begin{array}{l}\text { Pembelajaran Pendidikan Agama } \\
\text { Kristen memiliki potensi untuk } \\
\text { membangun karakter berwawasan } \\
\text { kebangsaan. }\end{array}$ & 13 & 65 & 5 & 25 & 2 & 10 & & & & & 20 \\
\hline 3 & $\begin{array}{l}\text { Pembelajaran Pendidikan Agama } \\
\text { Kristen dapat meningkatkan sikap } \\
\text { nasionalisme di tengah maraknya } \\
\text { isu-isu tindakan intoleransi dan } \\
\text { radikalisme. }\end{array}$ & 15 & 75 & 5 & 25 & & & & & & & 20 \\
\hline 4 & $\begin{array}{l}\text { Pendidikan Agama Kristen } \\
\text { mendukung gerakan revolusi mental } \\
\text { berlandaskan nilai-nilai kekristenan. }\end{array}$ & 12 & 60 & 7 & 35 & 1 & 5 & & & & & 20 \\
\hline 5 & $\begin{array}{l}\text { Diskusi tentang tema-tema } \\
\text { kebangsaan dalam Pendidikan } \\
\text { Agama Kristen dapat membangun } \\
\text { karakter berwawasan kebangsaan. }\end{array}$ & 10 & 50 & 8 & 40 & 2 & 10 & & & & & 20 \\
\hline 6 & $\begin{array}{l}\text { Saya menjaga keharmonisan } \\
\text { walaupun berbeda pandangan dan } \\
\text { pendapat dengan teman-teman. }\end{array}$ & 9 & 45 & 9 & 45 & 2 & 10 & & & & & 20 \\
\hline 7 & $\begin{array}{l}\text { Perbedaan latar belakang tidak } \\
\text { menjadi penghalang bagi saya untuk } \\
\text { membangun persahabatan }\end{array}$ & 5 & 25 & 8 & 40 & 7 & 35 & & & & & 20 \\
\hline 8 & $\begin{array}{l}\text { Saya menilai bahwa sikap radikal dan } \\
\text { intoleran timbul karena kurangnya } \\
\text { peran rohaniawan membina umatnya. }\end{array}$ & 13 & 65 & 7 & 35 & & & & & & & 20 \\
\hline 9 & $\begin{array}{l}\text { Jika terjadi perselisihan karena } \\
\text { perbedaan pandangan dan keimanan, } \\
\text { saya turun tangan mendamaikan. }\end{array}$ & 6 & 30 & 12 & 60 & 2 & 10 & & & & & 20 \\
\hline 10 & $\begin{array}{l}\text { Saya harus menerapkan pluralisme } \\
\text { untuk mencegah tindakan intoleransi } \\
\text { dan radikalisme. }\end{array}$ & 12 & 60 & 8 & 40 & & & & & & & 20 \\
\hline 11 & $\begin{array}{l}\text { Membangun kerjasama dalam } \\
\text { keberagaman dapat mencegah } \\
\text { tindakan intoleran dan radikal. }\end{array}$ & 9 & 45 & 11 & 55 & & & & & & & 20 \\
\hline 12 & $\begin{array}{l}\text { Sikap intoleran dan radikal terjadi } \\
\text { akibat kurangnya pembinaan tentang } \\
\text { nasionalisme melalui pendidikan. }\end{array}$ & 9 & 45 & 9 & 45 & 2 & 10 & & & & & 20 \\
\hline 13 & $\begin{array}{l}\text { Kegiatan-kegiatan sosial berwawasan } \\
\text { kebangsaan perlu dilakukan peserta } \\
\text { didik sebagai bagian gerakan revolusi } \\
\text { mental. }\end{array}$ & 7 & 35 & 12 & 60 & 1 & 5 & & & & & 20 \\
\hline 14 & $\begin{array}{l}\text { Gerakan Revolusi Mental mendorong } \\
\text { anda ikut menjaga kerukunan hidup } \\
\text { berbangsa dan mendukung } \\
\text { pemerintah. }\end{array}$ & 11 & 55 & 9 & 45 & & & & & & & 20 \\
\hline 15 & $\begin{array}{l}\text { Kerja kelompok dalam mengerjakan } \\
\text { tugas di sekolah sangat efektif untuk } \\
\text { membangun sikap mental toleransi } \\
\text { dalam keberagaman. }\end{array}$ & 9 & 45 & 11 & 55 & & & & & & & 20 \\
\hline
\end{tabular}


Penjabaran hasil kuesioner Tabel 1 adalah sebagai berikut:

1. $50 \%$ peserta didik sangat setuju dan $50 \%$ setuju menanggapi pernyataan bahwa Pembelajaran Pendidikan Agama Kristen (PAK) dapat membantu peserta didik memahami bahaya tindakan intoleransi dan radikalisme. Hal ini menunjukkan bahwa pembelajaran PAK memberikan pemahaman bagi peserta didik tentang bahaya tindakan radikalisme dan intoleransi.

2. $65 \%$ peserta didik sangat setuju, $25 \%$ setuju, dan $10 \%$ ragu-ragu terhadap pernyataan bahwa pembelajaran PAK memiliki potensi untuk membangun karakter peserta didik berwawasan kebangsaan. Hal ini menunjukkan bahwa pembelajaran PAK sangat membantu peserta didik dalam membangun karakter berwawasan kebangsaan.

3. $75 \%$ peserta didik sangat setuju, $25 \%$ setuju bahwa pembelajaran PAK dapat meningkatkan sikap nasionalisme di tengah maraknya isu-isu tindakan intoleransi dan radikalisme. Hal ini menunjukkan bahwa PAK sangat berpotensi meningkatkan sikap nasionalisme peserta didik di tengah maraknya isu-isu tindakan intoleransi dan radikalisme.

4. $60 \%$ peserta didik sangat setuju, $35 \%$ setuju, dan $5 \%$ ragu-ragu menyatakan bahwa PAK mendukung gerakan revolusi mental berlandaskan nilai-nilai kekristenan. Hal ini menunjukkan bahwa sebagian besar peserta didik sangat setuju bahwa PAK sejalan dengan gerakan revolusi mental yang berlandaskan nilai-nilai kekristenan.

5. $50 \%$ peserta didik sangat setuju, $40 \%$ setuju, dan $10 \%$ ragu-ragu menyatakan bahwa diskusi tentang tema-tema kebangsaan dalam PAK dapat membangun karakter berwawasan kebangsaan. Hal ini menunjukkan bahwa sebagian besar peserta didik sangat setuju dan hanya sebagian kecil ragu-ragu menyatakan bahwa diskusi tentang tema-tema kebangsaan dalam PAK dapat membangun karakter berwawasan kebangsaan.

6. $45 \%$ peserta didik sangat setuju, $45 \%$ setuju, dan $10 \%$ ragu-ragu menyatakan bahwa peserta didik menjaga keharmonisan walaupun berbeda pandangan dan pendapat dengan teman-teman. Hal ini menunjukkan bahwa sebagian besar peserta didik setuju dan hanya sebagian kecil ragu-ragu untuk menjaga keharmonisan walaupun berbeda pandangan dan pendapat dengan teman-teman. 
7. $25 \%$ peserta didik sangat setuju, $40 \%$ setuju, dan 35 ragu-ragu menyampaikan pandangan pribadi bahwa perbedaan latar belakang peserta didik tidak menjadi penghalang untuk membangun persahabatan. Hal ini menunjukkan bahwa sebagian besar peserta didik setuju dan sebagian kecil ragu-ragu menyatakan bahwa perbedaan latar belakang tidak menghalangi persahabatan di antara peserta didik.

8. $65 \%$ peserta didik sangat setuju dan $35 \%$ berpandangan bahwa sikap radikal dan intoleran timbul karena kurangnya peran rohaniawan membina umatnya. Hal ini menunjukkan bahwa sebagian besar peserta sangat setuju, tidak ada yang raguragu, menyatakan bahwa sikap radikal dan intoleran timbul karena kurangnya peran rohaniawan membina umatnya.

9. $30 \%$ peserta didik sangat setuju, $60 \%$ setuju, dan $10 \%$ ragu-ragu untuk menyatakan jika terjadi perselisihan karena perbedaan pandangan dan keimanan untuk turun tangan mendamaikan.. Hal ini menunjukkan bahwa sebagian besar peserta didik setuju dan sebagaian kecil ragu-ragu untuk turun tangan mendamaikan jika terjadi perselisihan karena perbedaan pandangan dan keimanan.

10. $60 \%$ peserta didik sangat setuju, $40 \%$ setuju bahwa peserta didik harus menerapkan pluralisme untuk mencegah tindakan intoleransi dan radikalisme. Hal ini menunjukkan bahwa sebagian besar peserta didik sangat setuju untuk menerapkan sikap pluralisme di tengah keberagaman untuk mencegah tindakan intoleransi dan radikalisme.

11. $45 \%$ peserta didik sangat setuju dan $55 \%$ setuju bahwa membangun kerjasama dalam keberagaman dapat mencegah tindakan intoleran dan radikal. Hal ini menunjukkan bahwa sebagian besar setuju untuk membangun kerjasama dalam keberagaman agar dapat mencegah tindakan intoleran dan radikal.

12. $45 \%$ peserta didik sangat setuju, $45 \%$ setuju, dan $10 \%$ ragu-ragu menyatakan bahwa sikap intoleran dan radikal terjadi akibat kurangnya pembinaan tentang nasionalisme melalui pendidikan. Hal ini menunjukkan bahwa sebagian besar peserta didik setuju dan hanya sebagian kecil ragu-ragu menyatakan bahwa sikap intoleran dan radikal terjadi akibat kurangnya pembinaan tentang nasionalisme melalui pendidikan. 
13. $35 \%$ peserta didik sangat setuju, $60 \%$ setuju, dan 5\% ragu-ragu terhadap kegiatan-kegiatan sosial berwawasan kebangsaan perlu dilakukan peserta didik sebagai bagian gerakan revolusi mental. Hal ini menunjukkan bahwa sebagian besar mahasiswa setuju bahwa kegiatan-kegiatan sosial berwawasan kebangsaan perlu dilakukan peserta didik sebagai bagian gerakan revolusi mental dan hal yang baik untuk dilakukan.

14. 55\% peserta didik sangat setuju, $45 \%$ setuju bahwa Gerakan Revolusi Mental mendorong peserta didik ikut menjaga kerukunan hidup berbangsa dan mendukung pemerintah. Hal ini menunjukkan bahwa sebagian besar peserta didik sangat setuju dengan menyatakan bahwa Gerakan Revolusi Mental dapat mendorong peserta didik untuk ikut menjaga kerukunan hidup berbangsa dan mendukung program pemerintah.

15. $45 \%$ peserta didik sangat setuju dan $55 \%$ setuju menyatakan bahwa kerja kelompok dalam mengerjakan tugas di sekolah sangat efektif untuk membangun sikap mental toleransi dalam keberagaman. Hal ini menunjukkan bahwa sebagian besar peserta didik setuju untuk melaksanakan kerja kelompok dalam mengerjakan tugas di sekolah untuk membangun sikap mental toleransi dalam keberagaman di sekolah.

Pertanyaan nomor 1 hingga 5 diajukan untuk mengidentifikasi pemahaman peserta didik tentang pembelajaran PAK untuk pembentukan karakter berwawasan kebangsaan. Jawaban dari 20 responden atau peserta didik sebagian besar menunjukkan bahwa peserta didik telah memahami pentingnya peranan pembelajaran PAK sebagai upaya untuk membangun karakter berwawasan kebangsaan, hanya sebagian kecil yang menjawab masih ragu-ragu. Pertanyaan nomor 6 hingga 10 untuk menemukan pemahaman peserta didik dalam menyikapi bahaya tindakan radikalisme dan intoleransi. Jawaban dari 20 responden ditemukan bahwa peserta didik sudah terbangun pemahaman tentang sikap yang harus mereka implementasikan dalam kehidupan seharihari meskipun masih ada yang ragu-ragu. Selanjutnya, pertanyaan nomor 11 hingga 15 untuk memberikan alternatif solusi dalam pembentukan karakter berwawasan kebangsaan untuk mencegah bahaya tindakan intoleransi dan radikalisme. Jawaban dari 20 peserta didik menunjukkan bahwa pembelajaran pendidikan agama Kristen berperan 
penting dalam membangun karakter berwawasan kebangsaan sebagai upaya untuk mendukung pemerintah dalam gerakan revolusi mental untuk mencegah sikap intoleran dan radikal.

Pengasuh Panti Asuhan Asih Lestari menyampaikan tanggapannya setelah penyuluhan, sebagai berikut: "Saya yakin, dengan memberikan penyuluhan bertemakan seperti intoleransi dan radikalisme akan memampukan mereka tetap menghadapi dengan tidak merasa takut terhadap tindakan brutal mereka. Melainkan, dengan kasihnya, diharapkan anak-anak asuh kami di Panti Asuhan Asih Lestari mampu menunjukkan kasih Tuhan terhadap bangsa ini melalui tindakan dan perbuatan yang takut akan Tuhan." Pendapat ini menandakan bahwa penyuluhan yang dilakukan di Panti Asuhan Asih Lestari memberikan dampak positif bagi pemahaman anak-anak asuh mengenai pentingnya toleransi dan berwawasan kebangsaan.

Dari hasil keseluruhan penelitian ini menunjukkan bahwa betapa pentingnya sosialisasi tentang gerakan revolusi mental dengan melibatkan pendidikan Kristen melalui pembelajaran PAK untuk membangun karakter anak bangsa agar berwawasan kebangsaan mulai dari sejak usia dini. Bahkan, pembentukan karakter berwawasan kebangsaan tidak cukup hanya di bangku sekolah tetapi juga wajib dilakukan melalui lingkungan keluarga, masyarakat, maupun gereja untuk membentuk karakter unggul anak bangsa menuju Indonesia maju.

\section{SIMPULAN}

Berdasarkan hasil kajian dari data empiris melalui penelitian yang dilakukan maka didapati bahwa: (a) Peserta didik memahami bahwa pembelajaran Pendidikan Agama Kristen memiliki peranan penting sebagai upaya untuk membangun karakter berwawasan kebangsaan. (b) Peserta didik mampu menyikapi isu-isu intoleransi dan radikalisme setelah mengikuti pembelajaran Pendidikan Agama Kristen untuk mencegah dan menghadapi bahaya tindakan intoleransi dan radikalisme terhadap kehidupan berbangsa. (c) Pembentukan karakter berwawasan kebangsaan melalui Pendidikan Agama Kristen dapat dijadikan upaya untuk mendukung gerakan revolusi mental bagi peserta didik Kristen sebagai alternatif solusi untuk mencegah tindakan intoleran dan radikal yang dapat mengganggu ketahanan nasional. Pendidikan Kristen 
hendaknya terus mengembangkan pembelajaran Pendidikan Agama Kristen sebagai upaya pembentukan karakter berwawasan kebangsaan bagi peserta didik Kristen agar memiliki sikap nasionalisme dan tidak terpapar pada tindakan-tindakan yang merusak tatanan kehidupan berbangsa. Peserta didik Kristen sebagai tunas bangsa harus memiliki karakter unggul dan tangguh serta berwawasan kebangsaan yang memiliki kemampuan dalam menghadapi persaingan global. Pendidik Kristen terus mengembangkan diri semakin profesional dalam mendidik untuk mempersiapkan generasi muda menuju Indonesia maju.

\section{DAFTAR PUSTAKA}

Anonim. (2019). Tempo.com.

BBC News. (2016). Ketika paham radikal masuk ke ruang kelas sekolah. https://www.bbc.com/indonesia/berita_indonesia/2016/05/160519_indonesia_lapsu s_radikalisme_anakmuda_sekolah

BBC News. (2018). Pelajar SMA di Padang, Sukabumi, dan Solo dianggap paling rentan terpapar radikalisme. https://www.bbc.com/indonesia/indonesia-42832938

Benawa, A. (2018). The Effectiveness of Full Day School System for Students' Character Building. IOP Publishing.

Detiknews.com. (2019). Menhan Sebut 23,4\% Mahasiswa di RI Terpapar Radikalisme.

Eliasaputra, M. P., Novalina, M., \& Siahaan, R. J. (2020). TANTANGAN PENDIDIKAN AGAMA KRISTEN DI ERA REVOLUSI INDUSTRI 4.0 DAN PASCA KEBENARAN. BONAFIDE: Jurnal Teologi Dan Pendidikan Kristen, 1(1), 1-22. https://doi.org/10.46558/bonafide.v1i1.7

Green, J. and N. T. (2004). Qualitative Methods for Health Research.

Jalaluddin, H., \& Idi, H. A. (2011). Filsafat pendidikan: manusia, filsafat, dan pendidikan. Divisi Buku Perguruan Tinggi, PT Rajagrafindo Persada.

Kasuistika. (2018). Miris, Radikalisme Tidak Hanya Menyasar Kampus, SD Juga Mulai Terpapar.

Kristiawan, M. (2016). Telaah Revolusi Mental dan Pendidikan Karakter dalam Pembentukkan Sumber Daya Manusia Indonesia Yang Pandai dan Berakhlak Mulia. Ta'dib.

Kumar, R. (2011). Research Methodology: A Step-by-Step Guide for Beginners No Title.

Li, L. (2004). Education for 1.3 Billion. Former Chinese Vice premier Li Lanqing on 10 Years of Education Reform and Development. Foreign Education and Research Press.

MA Widiyanto, A. F. (2020). Pengaruh Kompetensi Profesional Guru terhadap Minat Belajar Pendidikan Agama Kristen Siswa. Davar: Jurnal Teologi, 1(1), 65-73.

Martono, N. (2017). Sekolah Publik vs Sekolah Privat: dalam Wacana Kekuasaan, Demokrasi, dan Liberalisasi Pendidikan. Yayasan Pustaka Obor Indonesia.

Mastuhu. (1994). Dinamika sistem pendidikan pesantren: suatu kajian tentang unsur dan nilai sistem pendidikan pesantren. INIS.

Mawikere, M. C. S. (2020). Book Review: Desain Pendidikan Karakter: Konsepsi dan 
Aplikasinya dalam Lembaga Pendidikan. EDULEAD: Journal of Christian Education and Leadership, 1(2), 232-236.

https://doi.org/10.47530/edulead.v1i2.49

Nainggolan, T. (2015). Revolusi Mental Menuju Keserasian Sosial di Indonesia. Sosio Informa.

Nazir, M. (2005). Metode Penelitian.

Nego, O. (2020). Teologi Multikultural sebagai Respon terhadap Meningkatnya Eskalasi Politik Identitas di Indonesia. PASCA: Jurnal Teologi Dan Pendidikan Agama Kristen, 16(2), 121-139. https://doi.org/10.46494/psc.v16i2.109

Novalina, M. (2018). Di Bawah Kepak Sayap Sang Garuda (Pemahaman, Sikap dan Tindakan Fundamental Keber-Agama-an dalam Bingkai Pancasila) (T. S. Ekumene (ed.); 1st ed.). Rehobot Literature.

Novalina, M. (2020). Spiritualitas Orang Kristen Dalam Menghadirkan Kerajaan Allah di Tengah Tantangan Radikalisme. Jurnal Teologi Kontekstual Indonesia, 1(1), 26. https://doi.org/10.46445/jtki.v1i1.293

NU Online. (2018). Radikalisme yang menyebar secara senyap pada remaja dan pemuda. https://www.nu.or.id/post/read/90645/radikalisme-yang-menyebar-secarasenyap-pada-remaja-dan-pemuda

Nuhamara, D. (2018). Pengutamaan Dimensi Karakter Dalam Pendidikan Agama Kristen. Jurnal Jaffray, 16(1), 93. https://doi.org/10.25278/jj71.v16i1.278

Pike, M. A. (2010). Christianity and Character Education: Faith in Core Values? Journal of Beliefs \& Values, 31(3), 311-321.

Tilaar, H. A. R. (2000). Paradigma baru pendidikan nasional. Rineka Cipta.

Tirto. (2019). Setara Institute Sebut 10 Kampus Terpapar Paham Radikalisme.

Tracy, S. J. (2013). Qualitative Research Methods: Collecting Evidence, Crafting Analysis, Communicating Impact.

Zhafira, A. (2017). Efek moderasi kepercayaan politik terhadap hubungan antara religiusitas Islam dan intoleransi politik. Jurnal Psikologi Sosial, 15(2), 122-135. https://doi.org/10.7454/jps.2017.11 